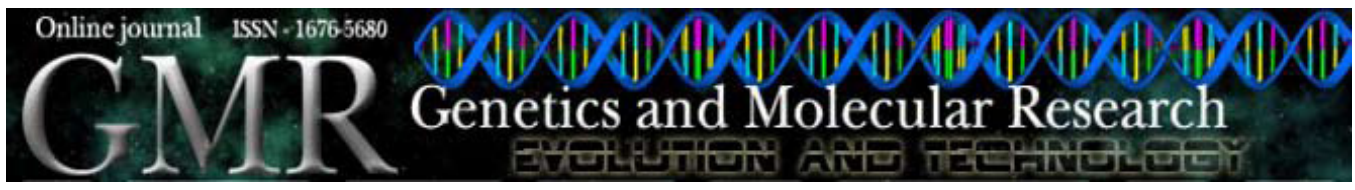

\title{
Ring chromosome instability evaluation in six patients with autosomal rings
}

\author{
C.P. Sodré', R.S. Guilherme' ${ }^{1}$, V.F.A. Meloni' ${ }^{1}$, D. Brunoni', \\ Y. Juliano ${ }^{3}$, J.A.D. Andrade ${ }^{1}$, S.I.N. Belangero' ${ }^{1}$, D.M. Christofolini ${ }^{1}$, \\ L.D. Kulikowski ${ }^{1,2}$ and M.I. Melaragno ${ }^{1}$ \\ 'Departamento de Morfologia e Genética da \\ Universidade Federal de São Paulo, São Paulo, SP, Brasil \\ ${ }^{2}$ Departamento de Patologia, LIM 03, \\ Universidade de São Paulo, São Paulo, SP, Brasil \\ ${ }^{3}$ Universidade de Santo Amaro, São Paulo, SP, Brasil
}

Corresponding author: M.I. Melaragno

E-mail: melaragno.morf@epm.br

Genet. Mol. Res. 9 (1): 134-143 (2010)

Received October 5, 2009

Accepted October 29, 2009

Published January 26, 2010

\begin{abstract}
Ring chromosomes are often associated with abnormal phenotypes due to loss of genomic material and also because of ring instability at mitosis after sister chromatid exchange events. We investigated ring chromosome instability in six patients with ring chromosomes $4,14,15$, and 18 by examining 48and 72-h lymphocyte cultures at the first, second and subsequent cell divisions after bromodeoxyuridine incorporation. Although most cells from all patients showed only one monocentric ring chromosome, ring chromosome loss and secondary aberrations were observed both in 48- and 72-h lymphocyte cultures and in
\end{abstract}


metaphase cells of the different cell generations. We found no clear-cut correlation between ring size and ring instability; we also did not find differences between apparently complete rings and rings with genetic material loss. The cytogenetic findings revealed secondary aberrations in all ring chromosome patients. We concluded that cells with ring chromosome instability can multiply and survive in vivo, and that they can influence the patient's phenotype.

Key words: Ring chromosome; Chromosome instability; Sister chromatid differentiation

\section{INTRODUCTION}

Ring chromosomes usually result from two terminal breaks in both chromosome arms, followed by fusion of the broken ends or from the union of a broken chromosome end with the opposite telomere region, leading to the loss of genetic material. Alternatively, they can be formed by subtelomeric sequence fusion or telomere-telomere fusion with no loss of genetic material, resulting in complete ring chromosomes (Henegariu et al., 1997; Sigurdardottir et al., 1999; Vermeesch et al., 2002; Le Caigne et al., 2004). Based on high-resolution molecular karyotyping, other mechanisms of the formation of ring chromosomes have been proposed, such as rings originating from an inverted duplication with a terminal deletion rearrangement (Knijnenburg et al., 2007; Rossi et al., 2008a).

In patients with ring chromosomes, further chromosomal abnormalities usually occur, due to sister chromatid exchange events during mitosis, which can result in dicentric rings, interlocked rings, and other structural conformations (Figure 1). These unstable chromosomes can lead to ring chromosome loss, producing monosomic cells, which may or may not be viable (Niss and Passarge, 1975; Ledbetter et al., 1980; Fang et al., 1995; Kosztolányi, 2009). Thus, ring chromosomes can vary in structure and number in an individual's somatic cells, resulting in a mosaic karyotype, a process called "dynamic tissue-specific mosaicism" (McDermott et al., 1977; Speevak et al., 2003).

This cytogenetic variation appears to depend mostly on ring size, rate of sister chromatid exchanges in the ring, and viability of the cell line with monosomy or with aberrant ring chromosomes (Kosztolányi, 1987a).

Ring chromosomes have been found for all human chromosomes. Usually the phenotype of ring chromosome patients overlaps that of the deletion of both ends of the respective chromosome syndromes (Schinzel, 2001). Nevertheless, the phenotypes associated with ring chromosomes are highly variable, since - in addition to the primary deletions associated with ring formation - secondary loss or gain of material may have occurred, due to the instability of ring chromosomes in general (Tümer et al., 2004; Purandare et al., 2005; Glass et al., 2006; Höckner et al., 2008; Zollino et al., 2009). Thus, the phenotype will actually depend on the size of the ring chromosome, the amount of euchromatin lost during ring formation, the ring stability, the presence of secondary aneuploid cells, and the rate of mosaicism (Kosztolányi, 1987a; Le Caigne et al., 2004). 


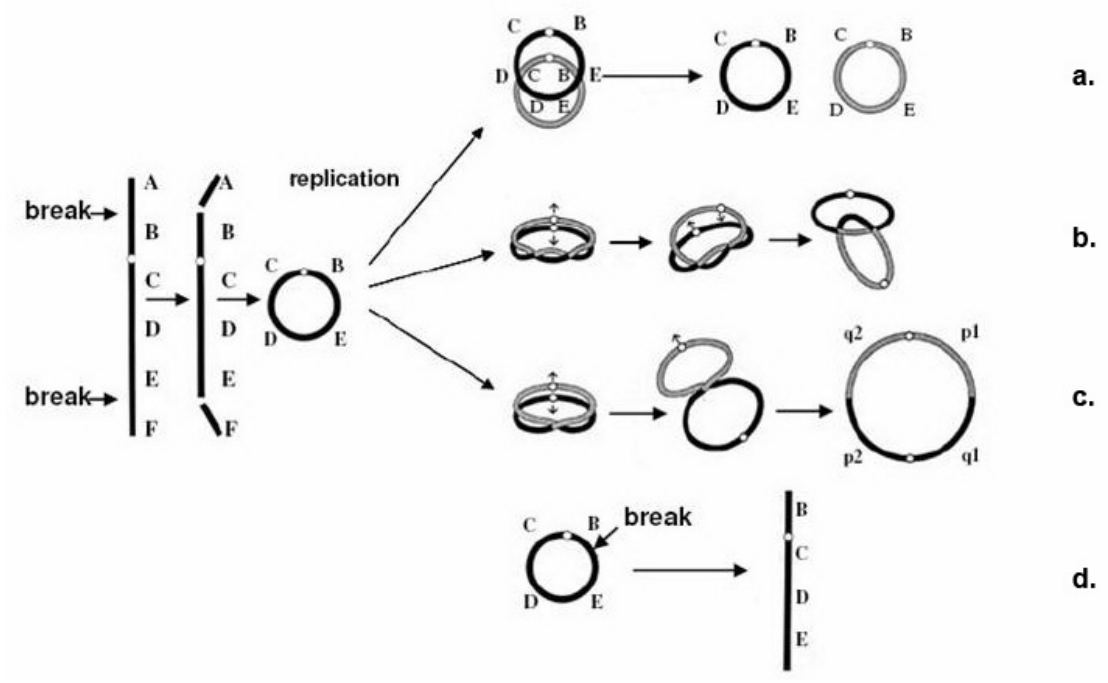

a.

b.

c.

d.

Figure 1. Scheme of ring formation and instability after replication, due to chromatid exchanges or breaks, originating: a. Two monocentric rings; b. Interlocked rings; c. Double-sized dicentric ring; d. Broken or open ring.

Cote et al. (1981) proposed the term "ring syndrome" to be used in the case of patients with apparently complete ring chromosomes who present severe intrauterine and growth retardation as the sole major physical abnormality, suggesting that the syndrome is not a consequence of the loss of genetic material but rather of cell death, due to the instability of ring chromosomes (Cote et al., 1981; Kosztolányi, 1987a). This idea was reconsidered by Rossi et al. (2008b) who believe that, at least in some ring chromosome patients, short stature is due to the haploinsufficiency of genes involved in stature. Thus, a cryptic deletion may be the basis of the phenotypic abnormalities in apparently complete rings, such as the deletion of the $I G F 1 R$ gene at $15 \mathrm{q} 26.3$ in a ring 15 . Also, the phenotypic variability seen in patients with similar ring chromosomes may be a consequence of their instability and of the variation in gene dosage of each cell (Hecht, 1969; Palmer et al., 1977; Zuffardi et al., 1980; Knijnenburg et al., 2007; Rossi et al., 2008a), as for instance in the patient with a ring 18 reported by Koç et al. (2008) who showed partial trisomy 18 in a considerable number of cells, due to the formation of dicentric rings, which resulted in a more severe phenotype. Rossi et al. (2008a) described a patient with a ring 13 who had a deletion and a duplication of approximately $6 \mathrm{Mb}$ each, oligohydramnios and cystic kidney, features that were attributed to trisomy 13. In the present study, the instability of the ring chromosomes of six patients was investigated. The different cell lines with ring chromosomes scored were obtained from 48- and 72-h lymphocyte cultures and also from metaphase cells in the first, second or more cell divisions in culture.

\section{PATIENTS AND METHODS}

Six patients (Figure 2) with de novo ring chromosomes were studied. 


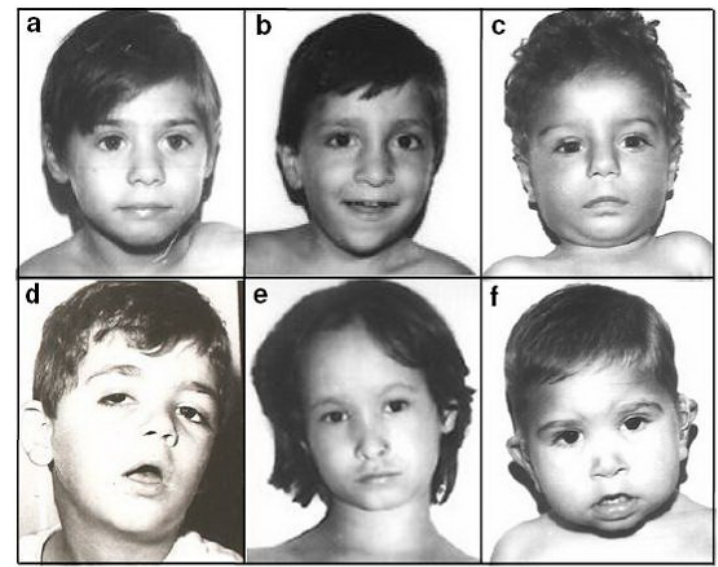

Figure 2. Frontal view of chromosomes from a. Patient I - ring 4; b. Patient II - ring 14; c. Patient III - ring 14; d. Patient IV - ring 14; e. Patient V - ring 15, and f. Patient VI - ring 18.

\section{Patient I}

Karyotype 46,XY,r(4)(p16q35). Born at term with a weight of $2200 \mathrm{~g}(<3 \mathrm{rd}$ centile), length of $43 \mathrm{~cm}(<3 \mathrm{rd}$ centile) and head circumference $(\mathrm{HC})$ of $31 \mathrm{~cm}(<3 \mathrm{rd}$ centile). Clinical examination at 4 years and 7 months of age showed normal neuromotor and mental development, microcephaly, brachycephaly, downslanting palpebral fissures, one café-au-lait spot on the thorax (skin pigmentary anomaly), and bilateral retractable testis.

\section{Patient II}

Karyotype 46,XY,r(14)(p13q32). Born at term, with a weight of $2800 \mathrm{~g}(\mathrm{P}=10)$, a length of $45 \mathrm{~cm}(\mathrm{P}=3)$, and $\mathrm{HC}$ of $31 \mathrm{~cm}(\mathrm{P}<3 \mathrm{rd}$ centile $)$. Clinical examination at 3 years of age revealed microcephaly, dolichocephaly, downslanting palpebral fissures, slightly prominent nose, broad nasal bridge, thin upper lip, high-arched palate, mild asymmetry of the upper central incisor teeth implantation, retrognathism, single palmar crease on the right, high anus implantation, and decreased subcutaneous tissue in the gluteus region. Skeleton X-rays revealed sacrum agenesis, hypertrophy of the muscles of the legs, club foot, prominent heels, bilateral short fourth metatarsal making the fourth toe appear short, café-au-lait spot in the left gluteus region, and seizures. He also had mild intellectual deficiency, limited verbal language repertoire, dysarthria, and a docile, affectionate and cooperative personality.

\section{Patient III}

46,XY,r(14)(p13q32). Born at term with a weight of $2030 \mathrm{~g}(\mathrm{P}<3$ rd centile), length $43 \mathrm{~cm}(\mathrm{P}<3 \mathrm{rd}$ centile $)$ and $\mathrm{HC} 30 \mathrm{~cm}(\mathrm{P}<3 \mathrm{rd}$ centile $)$. At birth, a noncyanotic congenital heart disease, severe perinatal anoxia, balanic hypospadia, sacrococcygeal pit, hypocalcemia, and hypomagnesemia were detected. At 6 months of age, interventricular communication, interatrial communication, and pulmonary stenosis with severe pulmonary 
hypertension were diagnosed, in addition to microcephaly, frontal hypertrichosis, short eyelids, epicanthic folds, long eyelashes, carp-shaped mouth, thin upper lip, two longitudinal grooves on the palate, retrognathism, bilateral clinodactyly of the fifth finger, some hypochromic and café-au-lait spots, a pigmented nevus on the hip, right cryptorchidism, general hirsutism, seizures, intellectual deficiency, and a docile and affectionate personality.

\section{Patient IV}

46,XY,r(14)(p11q32). Born at term weighing $2900 \mathrm{~g}(10<\mathrm{P}<25)$, measuring 46 $\mathrm{cm}(5<\mathrm{P}<10)$ and with $\mathrm{HC}$ of $32 \mathrm{~cm}(3<\mathrm{P}<5)$. Clinical examination at 9 years of age showed global muscle hypotonia, mild ataxia of trunk and limbs, brachymicrocephaly, occipital flattening, downslanting palpebral fissures, epicanthic folds, hypertelorism, esotropia, large and depressed nasal root, long philtrum, carp-shaped mouth, small and irregular teeth, high palate, large and posteriorly rotated ears, café-au-lait spots on the face and on the anterior-lateral side of the right forearm, and mild hirsutism. Fundoscopy showed retinitis pigmentosa. The patient displayed a hyperkinetic and puerile behavior, dysarthria and reduced verbal repertoire. He had seizures since 6 months of age.

\section{Patient V}

46,XX,r(15)(p13q26). Born at term, small for gestational age, weighing $2050 \mathrm{~g}$ $(<3$ rd centile), length $45 \mathrm{~cm}$ ( $3 \mathrm{rd}$ centile) and $\mathrm{HC}$ of $30 \mathrm{~cm}(<3 \mathrm{rd}$ centile). Clinical examination at 8 years and 10 months of age revealed microcephaly, brachycephaly, high forehead, exotropia, hypoplastic alae nasi, high-arched palate, retrognathism, bilateral clinodactyly of the fifth finger, abnormal palmar creases, hyperextensible knees, rough and dry skin on the lower limbs, generalized hirsutism, café-au-lait and small hypochromic spots spread over the face and the anterior region of the chest and abdomen. An X-ray of the spine showed dorso-lumbar scoliosis. She had mild intellectual disability, reduced verbal repertoire and a docile and cooperative personality.

\section{Patient VI}

46,XY,r(18)(p11.1q23). Born at term, small for gestational age, with a weight of 2500 $\mathrm{g}$ (5th centile), length $45 \mathrm{~cm}$ ( $3 \mathrm{rd}$ centile), and $\mathrm{HC}$ of $33 \mathrm{~cm}$ (10th centile). He had recurrent gastrointestinal infections, with bouts of intermittent fever and diarrhea. Clinical examination at 9 months of age showed microcephaly, generalized hypotonia, mainly of the upper limbs, thin hair with areas of scarcity, large and posteriorly rotated ears, nystagmus, bilateral epicanthic folds, depressed nasal root, slightly anteverted nares, mouth with downturned corners, high and narrow palate, retrognathism, short neck, congenital lymphedema of the back of hands and feet, incomplete palmar crease on the right, cryptorchidism and left vertical talus.

\section{Cytogenetic study}

Lymphocytes from peripheral blood samples were obtained from 48- and 72-h mitogen-stimulated cultures, prepared according to standard cytogenetic procedures. The 
slides were stained using solid staining, G- and C-banding, and also nucleolus organizer region (NOR)-staining for acrocentric ring chromosomes. For each individual, 600 metaphases were analyzed, 300 from 48 -h cultures and 300 from 72-h cultures.

In other culture samples, bromodeoxyuridine (BrdU) was added at a final concentration of $10 \mu \mathrm{g} / \mathrm{mL}$ for the entire culture period, for sister chromatid differentiation and culture cell cycle determination. Sister chromatid differentiation staining and staging of metaphase cells as first (M1), second (M2) and third or subsequent $(\geq M 3)$ mitosis in culture were performed as previously described (Melaragno and Smith, 1990). For each patient 400 cells were analyzed.

Metaphase cells were classified according to the number of chromosomes, the presence of a monocentric ring chromosome and the presence of derivative ring chromosomes (two monocentric rings, interlocked rings, double-sized dicentric ring, and broken or open ring).

For statistical analysis, the chi-square $\left(\chi^{2}\right)$ and the Fisher test were used, in order to compare the results from 48- and 72-h cultures, and a chi-square contingency test was applied to compare the results of $\mathrm{M} 1, \mathrm{M} 2$ and $\geq \mathrm{M} 3$ mitoses in culture.

\section{RESULTS}

G-banding revealed in patients I, II, III, and V ring chromosomes derived from chromosomes $4,14,14$, and 15 , respectively, with no apparent loss of genetic material. Patients IV and VI showed respectively a ring 14 and a ring 18, with deletion of the short arms. NOR-staining demonstrated the presence of an NOR in two of the three ring 14 patients (II and III) and in the ring 15.

Tables 1 and 2 show the total number of metaphases analyzed, as well as the number and frequency of cells with and without the ring chromosomes and of cells with secondary aberrations derived from the ring chromosome, considering the mitoses in culture.

Table 1. Number and percent of metaphase cells considering the chromosome number and the presence of secondary aberrations found in 300 cells analyzed from each of 48- and 72-h lymphocyte cultures.

\begin{tabular}{|c|c|c|c|c|c|c|}
\hline Patient & Ring & Culture time & $\begin{array}{l}\text { Cells with } 46 \text { chromosomes } \\
\text { and one monocentric } \\
\text { ring chromosome }\end{array}$ & $\begin{array}{l}\text { Cells with } 45 \\
\text { chromosomes lacking } \\
\text { ring chromosome }\end{array}$ & $\begin{array}{l}\text { Cells with secondary } \\
\text { structural aberrations }\end{array}$ & $\begin{array}{l}\text { Total cells } \\
\text { analyzed }\end{array}$ \\
\hline \multirow[t]{3}{*}{ I } & \multirow[t]{3}{*}{$\mathrm{r}(4)(\mathrm{p} 16 \mathrm{q} 35)$} & $48 \mathrm{~h}$ & $286(95.3 \%)$ & $5(1.7 \%)$ & $9(3.0 \%)$ & 300 \\
\hline & & $72 \mathrm{~h}$ & $270(90.0 \%)$ & $4(1.3 \%)$ & $26(8.7 \%)$ & 300 \\
\hline & & & $\chi^{2}=6.28^{*}$ & $\mathrm{P}=0.7523$ & $\chi^{2}=8.77^{*}$ & \\
\hline \multirow[t]{3}{*}{ II } & \multirow[t]{3}{*}{$\mathrm{r}(14)(\mathrm{p} 13 \mathrm{q} 32)$} & $48 \mathrm{~h}$ & $293(97.7 \%)$ & $1(0.3 \%)$ & $6(2.0 \%)$ & 300 \\
\hline & & $72 \mathrm{~h}$ & $287(95.7 \%)$ & $1(0.3 \%)$ & $12(4.0 \%)$ & 300 \\
\hline & & & $\chi^{2}=1.86$ & $\mathrm{P}=1.00$ & $\chi^{2}=2.06$ & \\
\hline \multirow[t]{3}{*}{ III } & \multirow[t]{3}{*}{$\mathrm{r}(14)(\mathrm{p} 13 \mathrm{q} 32)$} & $48 \mathrm{~h}$ & $292(97.3 \%)$ & $1(0.3 \%)$ & $7(2.3 \%)$ & 300 \\
\hline & & $72 \mathrm{~h}$ & $277(92.3 \%)$ & $16(5.3 \%)$ & $7(2.3 \%)$ & 300 \\
\hline & & & $\chi^{2}=7.65^{*}$ & $\mathrm{P}=0.0002 *$ & $\chi^{2}=0.00$ & \\
\hline \multirow[t]{3}{*}{ IV } & \multirow[t]{3}{*}{$\mathrm{r}(14)(\mathrm{p} 11 \mathrm{q} 32)$} & $48 \mathrm{~h}$ & $287(95.7 \%)$ & $3(1.0 \%)$ & $10(3.3 \%)$ & 300 \\
\hline & & $72 \mathrm{~h}$ & $274(91.3 \%)$ & $12(4.0 \%)$ & $14(4.7 \%)$ & 300 \\
\hline & & & $\chi^{2}=4.64 *$ & $\mathrm{P}=0.0330^{*}$ & $\chi^{2}=0.69$ & \\
\hline \multirow[t]{3}{*}{ V } & \multirow[t]{3}{*}{$\mathrm{r}(15)(\mathrm{p} 13 \mathrm{q} 26)$} & $48 \mathrm{~h}$ & $271(90.3 \%)$ & $9(3.0 \%)$ & $20(6.7 \%)$ & 300 \\
\hline & & $72 \mathrm{~h}$ & $286(95.3 \%)$ & $5(1.7 \%)$ & $9(3.0 \%)$ & 300 \\
\hline & & & $\chi^{2}=5.64 *$ & $\mathrm{P}=1.17$ & $\chi^{2}=4.38^{*}$ & \\
\hline \multirow[t]{3}{*}{ VI } & \multirow[t]{3}{*}{$\mathrm{r}(18)(\mathrm{p} 11.1 \mathrm{q} 23)$} & $48 \mathrm{~h}$ & $277(92.3 \%)$ & $0(0 \%)$ & $23(7.7 \%)$ & 300 \\
\hline & & $72 \mathrm{~h}$ & $274(91.3 \%)$ & $7(2.3 \%)$ & $19(6.3 \%)$ & 300 \\
\hline & & & $\chi^{2}=0.20$ & $\mathrm{P}=0.0151 *$ & $\chi^{2}=0.41$ & \\
\hline Total from & & $48 \mathrm{~h}$ & $1706(94.8 \%)$ & $19(1.1 \%)$ & $75(4.2 \%)$ & 1800 \\
\hline \multirow[t]{2}{*}{ all patients } & & $72 \mathrm{~h}$ & $1668(92.7 \%)$ & $45(2.5 \%)$ & $87(4.8 \%)$ & 1800 \\
\hline & & & $\chi^{2}=6.81 *$ & $\mathrm{P}=10.75^{*}$ & $\chi^{2}=0.93$ & \\
\hline
\end{tabular}

Data are reported as number with percent in parentheses. 


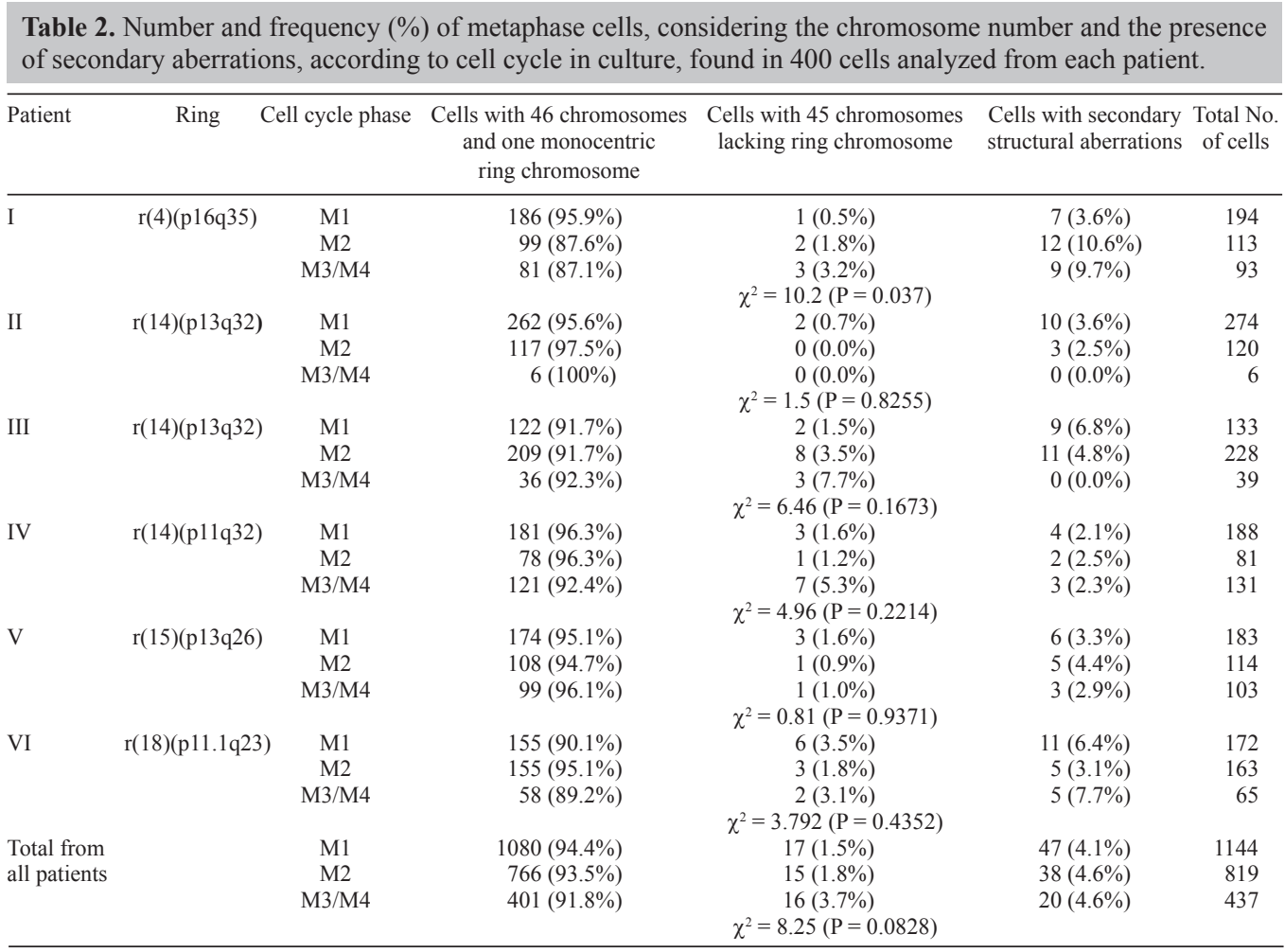

Data are reported as number with percent in parentheses.

The secondary aberrations found in patients with ring chromosomes were, in decreasing order of frequency, dicentric ring chromosomes, two or three monocentric or dicentric ring chromosomes in the same cell, open rings, and chromosome fragments (Figure 3).

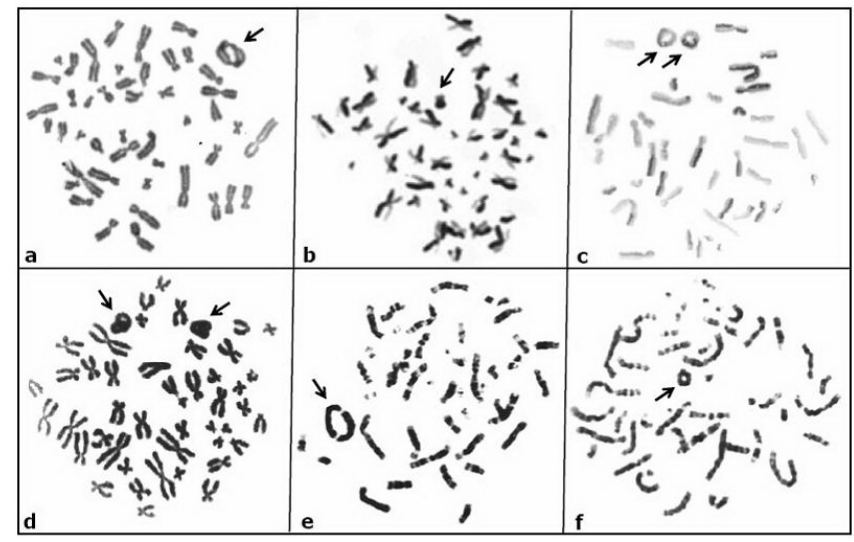

Figure 3. Metaphase cells showing ring chromosome instability: (a), (b) and (c) show cells in their first, second and third division in culture using BrdU incorporation. Arrows show ring chromosomes varying in number and morphology: (a, e) dicentric ring 4, (b) opened ring 14, (c) two dicentric rings 14, (d) two monocentric rings 4, (f) dicentric ring 18. 


\section{DISCUSSION}

In all patients, most cells analyzed (90 to $97.7 \%$ ) showed only one monocentric ring chromosome, as previously described in different reports concerning 48- and 72-h cultures of patients with ring chromosomes. The percentage of cells with 45 chromosomes due to ring loss and of cells with secondary structural aberrations varied from zero to 5.3 and from 2.0 to 8.7 , respectively.

In a study by Kosztolányi (1987a), a ring chromosome was considered to be "stable" when secondary aberrations were found in $0-5 \%$ of the mitoses and "unstable" when such aberrations occurred in more than $5 \%$ of the mitoses counted.

We found that the cells showing ring chromosome instability can vary among different ring chromosomes $(4,14,15$, and 18) and even when the ring chromosome is the same, as shown by our three ring 14 cases, a finding also reported by Chitayat et al. (1987).

In 48 -h cultures, the ring 4 and all ring 14 chromosomes were considered to be stable, whereas rings 15 and 18 were unstable. In 72-h cultures, ring 4, two of the three ring 14 chromosomes and ring 18 can be considered unstable. We found no clear correlation between ring size and ring instability, as suggested by Lejeune (1967) and Kosztolányi (1987a), and no difference between apparently complete rings and rings with genetic material deletion.

In patients I, II and IV, we found a smaller number of cells with one monocentric ring in the 72-h cultures compared to the 48-h cultures, along with an increase in the frequency of cells showing instability of the ring chromosomes; yet, in patient V, we observed the opposite. When we scored the cells after BrdU incorporation for cell cycle differentiation, we found a significant alteration in the different cell types only regarding patient I (ring 4), who showed a decrease in the percentage of cells with one monocentric ring chromosome with each cell generation in culture.

Tsukino et al. (1980) and Riley et al. (1981) also observed an increase in the frequency of monosomic cells for the ring chromosomes as the lymphocyte culture time increased. Tsukino et al. (1980) attributed this finding to ring chromosome instability in vivo, while Riley et al. (1981) considered them as resulting from in vitro ring loss, since they believed that these cells were not viable in vivo.

Cote et al. (1981), using BrdU for cell cycle determination in 48- and 72-h cultures, found secondary aberrations exclusively in cells after two cell cycles in culture, and suggested that these cells would not survive in vivo and that the frequency of cells showing secondary aberrations in the second cell cycle in culture would be the same as the rate of cell death in vivo.

Kosztolányi and Pap (1986) and Kosztolányi (1987b) studied two cases of ring chromosomes (ring 4 and ring 15) that were shown to be unstable both in lymphocyte and fibroblast cultures. An increased cell death rate was detected by cell viability determination with Trypan blue exclusion in fibroblast cultures. Since ring derivative chromosomes could also be seen in lymphocytes after only one cycle in culture, the authors suggested that such cells are also generated in vivo and that behavioral instability of rings at mitosis probably occurs in vivo as well.

A variation in the stability of ring chromosomes was also found among different tissues. Some researchers found higher frequencies of monosomic cells without the ring chromosomes in fibroblast compared to lymphocyte cultures (Sparkes et al., 1967; Moore et al., 1973; Palmer et al., 1977; Peeden et al., 1983), while others found no significant differences between the two tissues (Valente et al., 1977; Ledbetter et al., 1980; Manouvrier-Hanu et al., 1988). Ledbetter et al. (1980), however, found ring chromosomes 15 with an abnormal morphology in $9 \%$ of metaphase cells from lymphocyte cultures and in 20 and $24 \%$ of cells from fibroblast cultures in the third and tenth subculture, respectively, although it was not possible to know if these cells were formed de novo or were perpetuated in a clonal manner. Manouvrier-Hanu 
et al. (1988) also found a higher frequency of cells with two ring chromosomes 9 in fibroblast compared to lymphocyte cultures.

Cote et al. (1981) and Kosztolányi (1985) suggested that cells with secondary aberrations would not survive in vivo, where they would be eliminated in the following cell divisions. Different conclusions were drawn by Hernandez et al. (1979), who found similar frequencies of cells containing only one ring 13, of monosomic cells and of cells with different types of ring chromosomes in 48-, 72- and 96-h lymphocyte cultures, and also by de Almeida et al. (1983) who found no monocentric ring chromosome 13 in either 48- or 72-h lymphocyte cultures and who concluded that these chromosomes were unlikely to be produced in vitro.

In the present study, cytogenetic data revealed in all ring chromosome patients the presence of secondary aberrations in 48- and 72-h lymphocyte cultures and also in metaphase cells that were in different cultured cell generations. Considering both our data and those from the literature, we believe that cells derived from ring chromosome instability can multiply and survive in vivo, and may have an influence on the phenotypic variations of patients with ring chromosomes.

\section{REFERENCES}

Chitayat D, Hahm SY, Iqbal MA and Nitowsky HM (1987). Ring chromosome 6: report of a patient and literature review. Am. J. Med. Genet. 26: 145-151.

Cote GB, Katsantoni A and Deligeorgis D (1981). The cytogenetic and clinical implications of a ring chromosome 2. Ann. Genet. 24: 231-235.

de Almeida JC, Llerena JC Jr, Gomes DM, Martins RR, et al. (1983). Ring 13 in an adult male with a 13:13 translocation mother. Ann. Genet. 26: 112-115.

Fang YY, Eyre HJ, Bohlander SK, Estop A, et al. (1995). Mechanisms of small ring formation suggested by the molecular characterization of two small accessory ring chromosomes derived from chromosome 4. Am. J. Hum. Genet. 57: 1137-1142.

Glass IA, Rauen KA, Chen E, Parkes J, et al. (2006). Ring chromosome 15: characterization by array CGH. Hum. Genet. 118: 611-617.

Hecht F (1969). Ring-4 chromosome: Ring autosomes, Lorelei of clinical-kaotype correlation and deletion mapping. Birth Defects: Original Article Series V: 106-113.

Henegariu O, Pescovitz OH, Vance GH, Verbrugge J, et al. (1997). A case with mosaic di-, tetra-, and octacentric ring Y chromosomes. Am. J. Med. Genet. 71: 426-429.

Hernandez A, Garcia-Cruz D, Plascencia L, Nazara Z, et al. (1979). Some clinical and cytogenetic observations on a ring chromosome 13 (p11 q34). Ann. Genet. 22: 221-224.

Hockner M, Utermann B, Erdel M, Fauth C, et al. (2008). Molecular characterization of a de novo ring chromosome 6 in a growth retarded but otherwise healthy woman. Am. J. Med. Genet. A 146: 925-929.

Knijnenburg J, van Haeringen A, Hansson KB, Lankester A, et al. (2007). Ring chromosome formation as a novel escape mechanism in patients with inverted duplication and terminal deletion. Eur. J. Hum. Genet. 15: 548-555.

Koç A, Kan D, Karaer K, Ergun MA, et al. (2008). An unexpected finding in a child with neurological problems: mosaic ring chromosome 18. Eur. J. Pediatr. 167: 655-659.

Kosztolányi G (1985). Ring chromosome 4: Wolf syndrome and unspecific developmental anomalies. Acta Paediatr. Hung. 26: 157-165.

Kosztolányi G (1987a). Does "ring syndrome" exist? An analysis of 207 case reports on patients with a ring autosome. Hum. Genet. 75: 174-179.

Kosztolányi G (1987b). Decreased cell viability of fibroblasts from two patients with a ring chromosome: an in vitro reflection of growth failure? Am. J. Med. Genet. 28: 181-184.

Kosztolányi G (2009). The genetics and clinical caracteristics of constitutional ring chromosomes. J. Assoc. Genet. Technol. 35: 44-48.

Kosztolányi G and Pap M (1986). Severe growth failure associated with atrophic intestinal mucosa and ring chromosome 15. Acta Paediatr. Scand. 75: 326-331.

Le Caigne C, Boceno M, Jacquemont S, Nguyen The Tich S, et al. (2004). Inherited ring chromosome 8 without loss of subtelomeric sequences. Ann. Genet. 47: 289-296.

Ledbetter DH, Riccardi VM, Au WW, Wilson DP, et al. (1980). Ring chromosome 15: phenotype, Ag-NOR analysis,

Genetics and Molecular Research 9 (1): 134-143 (2010)

CFUNPEC-RP www.funpecrp.com.br 
secondary aneuploidy, and associated chromosome instability. Cytogenet. Cell Genet. 27: 111-122.

Lejeune JJ (1967). Modèle théorique de la répartition des duplications et des déficiences dans les chromosomes en anneau. C. R. Acad. Sci. Paris 264: 2568-2590.

Manouvrier-Hanu S, Turck D, Gottrand F, Savary JB, et al. (1988). Le chromosome 9 en anneau: à propos d'un cas et revue de la literature. (Rirg chromosome 9 p. Report of a case and review of literature). Ann. Genet. 31: 250-253.

McDermott A, Voyce MA and Romain D (1977). Ring chromosome 4. J. Med. Genet. 14: 228-232.

Melaragno MI and Smith MA (1990). Sister chromatid exchange and proliferation pattern in lymphocytes from newborns, elderly subjects and in premature aging syndromes. Mech. Ageing Dev. 54: 43-53.

Moore CM, Heller RH and Thomas GH (1973). Developmental abnormalities associated with a ring chromosome 6. J. Med. Genet. 10: 299-303.

Niss R and Passarge E (1975). Derivative chromosomal structures from a ring chromosome 4. Humangenetik 28: 9-23.

Palmer CG, Hodes ME, Reed T and Kojetin J (1977). Four new cases of ring 21 and 22 including familial transmission of ring 21. J. Med. Genet. 14: 54-60.

Peeden JN, Scarbrough P, Taysi K, Wilroy RS, et al. (1983). Ring chromosome 6: variability in phenotypic expression. Am. J. Med. Genet. 16: 563-573.

Purandare SM, Lee J, Hassed S, Steele MI, et al. (2005). Ring chromosome 9 [r(9)(p24q34)]: a report of two cases. $A m$. J. Med. Genet. A 138A: 229-235.

Riley SB, Buckton KE, Ratcliffe SG and Syme J (1981). Inheritance of a ring 14 chromosome. J. Med. Genet. 18: 209-213.

Rossi E, Riegel M, Messa J, Gimelli S, et al. (2008a). Duplications in addition to terminal deletions are present in a proportion of ring chromosomes: clues to the mechanisms of formation. J. Med. Genet. 45: 147-154.

Rossi E, Messa J and Zuffardi O (2008b). Ring syndrome: still true? J. Med. Genet. 45: 766-768.

Schinzel A (2001). Catalogue of Unbalanced Chromosome Aberrations in Man. 2nd edn. Walter de Gruyter, Berlin.

Sigurdardottir S, Goodman BK, Rutberg J, Thomas GH, et al. (1999). Clinical, cytogenetic, and fluorescence in situ hybridization findings in two cases of "complete ring" syndrome. Am. J. Med. Genet. 87: 384-390.

Sparkes RS, Carrel RE and Wright SW (1967). Absent thumbs with a ring D2 chromosome: a new deletion syndrome. Am. J. Hum. Genet. 19: 644-659.

Speevak MD, Smart C, Unwin L, Bell M, et al. (2003). Molecular characterization of an inherited ring (19) demonstrating ring opening. Am. J. Med. Genet. A 121A: 141-145.

Tsukino R, Tsuda N, Dezawa T, Ishii T, et al. (1980). Ring chromosome 10:46,XX,r(10)(p15 leads to q26). J. Med. Genet. 17: $148-150$.

Tümer Z, Harboe TL, Blennow E, Kalscheuer VM, et al. (2004). Molecular cytogenetic characterization of ring chromosome 15 in three unrelated patients. Am. J. Med. Genet. A 130A: 340-344.

Valente M, Muller H and Sparkes RS (1977). Ring 11 chromosome (46,xx,r11(p15q25)). Hum. Genet. 36: 345-350.

Vermeesch JR, Baten E, Fryns JP and Devriendt K (2002). Ring syndrome caused by ring chromosome 7 without loss of subtelomeric sequences. Clin. Genet. 62: 415-417.

Zollino M, Seminara L, Orteschi D, Gobbi G, et al. (2009). The ring 14 syndrome: clinical and molecular definition. $\mathrm{Am}$. J. Med. Genet. A 149A: 1116-1124.

Zuffardi O, Danesino C, Poloni L, Pavesi F, et al. (1980). Ring chromosome and latent centromeres. Cytogenet. Cell Genet. 28: 151-157. 